\title{
Preface
}

Los Angeles ... No ordinary rules explain its past growth or set limits to its future expansion. It has been, and will be, a law unto itself.

WILLIAM E. SMYTHE, The Conquest of Arid America

\section{A HISTORIC DISPUTE}

William Mulholland presided over the creation of a water system that changed forever the course of Southern California history, and in so doing he became the focus of a controversy that has never died. When Los Angeles went water hunting and laid claim to the waters of the Owens River over two hundred miles away, its actions so conflicted with competing interests that they gave rise to a struggle of mythic proportions. Reading the varying accounts of this action reminds one of the classic paradox All Cretans are liars, said the man from Crete. Who lies? Does everyone lie or does everyone one tell the truth? Even if the dead could be brought back, could they tell us what we want to know? Writers who have scrutinized the same public documents, official records, and private correspondence have arrived at contrary conclusions, so the existing literature on the story of Los Angeles's water is not only voluminous but also often dissonant.

When I began research for this work in I989, four books on the subject especially deserved serious consideration, each offering different yet valuable versions of the water story. The important pioneer effort was The Water Seekers (1950), by Remi Nadeau, a highly readable work that subsequent scholarship has somewhat superseded. Water and Politics: A Study of Water Policies and Administration in the Development of Los Angeles (1953), by Vincent Ostrom, is probably the best and most 
precise single survey of the subject but tends to be impersonal in its treatment of the individuals involved in the story. Vision or Villainy: Origins of the Owens Valley-Los Angeles Water Controversy (I98I), by Abraham Hoffman, is a fair-minded and thorough work, especially valuable for its examination of the roles J. B. Lippincott and the Reclamation Service played in the Owens Valley saga. The fourth, Water and Power (1982), by William Kahrl (editor of the estimable California Water Atlas), while containing a wealth of documentation, technical information, and a valuable bibliography, is also full of inaccuracies and, because of its unremittingly jaundiced view of Los Angeles and its water seekers, ultimately proves to be a polemic masquerading as a scholarly study. Water and Power has been influential, however, in subsequent works that have relied and elaborated on Kahrl's views: Cadillac Desert (I986), a screed by Marc Reisner on the evils of water development in the West; Western Times and Water Wars (1992), by John Walton, a study of Owens Valley that is somewhat in the manner of the Annales school of French historiography as found in LeRoy Ladurie's Montail$l o u$ and that describes the purported injustice inflicted by large governmental power over a small region; and The Lost Frontier (I994), by John Sauder, an inquiry into the agricultural losses sustained in Owens Valley because of Los Angeles's water development. Although none of the authors of this latter group is as extreme as the popular Western writer Wallace Stegner, who wrote that he considered building a dam evidence of original sin, each reflects the fin de siècle skepticism toward large water projects along with a disapproval of Los Angeles and a resolute bias favoring Owens Valley. The inclination to side with the underdog is powerful and humane but also risks committing what Bertrand Russell called "the fallacy of the superior virtue of the oppressed." Even the objective scholar-historian Norris Hundley has described Los Angeles as "the West's most notorious water hustler" in Water and the West (1975), and in his extensive overview of California water history, The Great Thirst (I992), he trivializes the building of the Owens Valley Aqueduct under a pejorative chapter heading, "The Owens Valley Caper." These works' contentions have helped create public perceptions such as a woman recently voiced at an environmental conference I attended when she fairly shouted, "Mulholland was no engineer. All he did was take a few pipes up north and run water down and help make some men rich," or such as a recent news article expressed when it described "the shadowy fiddling that sucked Owens Valley water into Los Angeles." In these versions, Mulholland emerges as an antihero rather than an admired bringer 
of water. As one of his nieces once ruefully remarked, "The Greeks beat the Trojans, but now, after three thousand years, it is a greater compliment to be called a Trojan."

In fact, the whole thrust of the Los Angeles enterprise looked to the future. Just as Caesar did not look back to Alexander for his model of a Roman empire but anticipated as a model a kind of city-state existing in Rome's own peripheries and provinces, so the leaders of an expanding Los Angeles looked to extend boundaries in order to create a new kind of city. What, after all, made this venture more reprehensible than those undertaken by other American cities that had gone distances to find water: New York to Croton, Boston to Lake Winnipesaukee, and San Francisco to the Tuolumne River in the Sierra Nevada mountain range? Who still rails against the New York Catskill project, which in its construction bought and drowned ten towns and villages, removed three thousand dead from thirty-two cemeteries, relocated eleven miles of rail track, and built ten highway bridges? Furthermore, the New York project was simply a water delivery system, while the Owens River project was to produce electrical energy as well, making it at the time not only a municipally owned utility but also one of the most valuable commercial enterprises in the United States.

\section{SOURCES AND THE ROLE OF THE PRESS}

Newspapers, the "diaries of history," have been a rich source for the present work. Because the Los Angeles Times has outlived its former competitors, files of those defunct papers must now be sought in selected libraries where, in many cases, they exist only in incomplete runs. While the chief creators of the Times, General Harrison Gray Otis and Harry Chandler, enjoy enormous fame in the city's history, few trails of glory follow Colonel J. J. Ayers, Major Horace Bell, Manchester Boddy, Edward Dickson, Edwin T. Earl, J. D. Lynch, and Benjamin C. Truman. Yet all once either owned, published, and/or edited successful and influential newspapers in Los Angeles with editorial slants that are sometimes today overlooked or forgotten. Especially among journalists and popular historians, this imbalance has led to an inflation of the roles of Otis and Chandler as city-makers out of all proportion to the facts. Without in any way minimizing these powerful men's impact on the city's history, I have tried to introduce other opinion-molders who played roles in building the City of Los Angeles.

One must keep alert, however, to journalist Mark Sullivan's caveat 
that "a newspaper, as respects its fundamental character, is one of the least permanent of institutions ... it can change ownership overnight," and that "even though it remain in the same ownership, its character, point of view, and policy may be altered by a change in the owner's interests, by his necessity for borrowing money, or otherwise" (Our Times, vol. 2, pp. 228-29). A new editor, or even a change in the post of managing-editor, can switch the emphasis upon the coverage of certain subjects. Otis's Times, for example, considered the leading booster for building the aqueduct and creating a municipal water system, became, under the later aegis of Harry Chandler, an implacable foe of the Boulder Dam project and the expansion of municipal power. Hearst's Examiner also reversed itself, beginning as an editorial foe of the aqueduct and ending as its champion, as well as later supporting Boulder Dam and the municipal ownership of water and power.

Archival papers of civic leaders and engineers also proved helpful because they document many of the interconnections between business interests and the water story of Los Angeles. Mulholland's friendship with Henry O'Melveny and Charles Dwight Willard was further demonstrated in their papers and journals, while those of political leaders John R. Haynes and Meyer Lissner augment the public record of their relationships during the rise of progressivism in Los Angeles and California.

\section{ANOTHER VOICE ON THE SUBJEGT}

Biographies of engineers are scarce since they must deal with technical matters often beyond the ken of historian or biographer. Because the public and administrative life of an engineer tends to overshadow the private, it becomes the biographer's duty to render that public side in vivid, yet accurate, style. Aside from memoirs written soon after his death by close associates (engineers J. B. Lippincott and Harvey Van Norman), the first attempt at a biography of William Mulholland was a monograph, William Mulholland: A Forgotten Forefather (1976), by Robert Matson. Written for a master's degree at the University of the Pacific, it derives mostly from secondary materials and is only a partial account of the engineer's life. Rivers in the Desert (1993), by Margaret Leslie Davis, purports to be a "major biography" but is not. Mulholland's first fifty years remain unexplored, while accounts of his private and domestic life rely on hearsay and public records of marriage, divorce, and probate. Marred by many minor factual errors, the work 
demonstrates little depth of understanding about the complexity of the water story.

For background and information to supplement personal knowledge of the years when Mulholland was an anonymous figure in Los Angeles (I 878-I904), I turned to city council proceedings, Department of Water and Power records, and reminiscences of Mulholland's early employees and associates. Only scanty information remains from the years I 888 to I902, when he headed the private water company that ran the city's system. With records either lost or destroyed, the Times here proved valuable, as it provided the most detailed coverage of city council meetings during those years, when the official proceedings tended to be skeletal. Family scrapbooks, papers, and reminiscences were also useful, but especially helpful were Mulholland's office files (1902-I928) from the Los Angeles Water Department, which only in recent years have been discovered, catalogued, and made available.

This work is not only a biography of William Mulholland but also an account of how a small pueblo in a semiarid basin was able to secure the water and power that allowed it to grow into a major city. It describes the many associates-some heroic, some not-who worked in this epic endeavor. Because the water story remains the founding myth of modern Los Angeles, this work also calls into question many current versions of the so-called Owens Valley controversy. Was there really rape and betrayal by the city's leaders? Was the entire building of the Owens Valley Aqueduct the result of a conspiracy among Los Angeles capitalists to acquire water in order to develop for speculation their holdings in the San Fernando Valley? Who were the chief enemies of the city's water seekers? Also discussed are the developments leading to the building of Boulder Dam and, finally, the major disaster of the Saint Francis Dam (I928), which ended Mulholland's career.

The epigraph by Tacitus from Robert Graves's I, Claudius underscores the problems inherent in telling this story, with which in a sense I have lived all my life and which even now may be disbelieved, so fixed in some minds is the certainty of what transpired that nothing would alter their opinion. As the subject's granddaughter, my objectivity will be questioned. To answer that, I turn again to Tacitus, who almost two thousand years ago wrote of the profoundly divided opinions of those who were "bitterly alienated" by an event and those who were "deeply committed" to it: "But whereas the reader can easily discount the bias of the time-serving historian, detraction and spite find a ready audience. 
Adulation bears the ugly taint of subservience, but malice gives the false impression of being independent." When the Chinese general Chou en Lai was asked in the I950s what he thought had been the French Revolution's impact on western Europe, he replied that it was too soon to tell. Without insisting on Chou's long view, I would suggest that if there is to be a last word on this saga, it is yet to come. I also believe that diverse voices should continue to be heard, and I hope that mine will be among them. 